\title{
IN VITRO TESTING OF ESTRAGOLE IN HEPG2 CELLS: CYTOKINESIS-BLOCK MICRONUCLEUS ASSAY AND CELL-CYCLE ANALYSIS
}

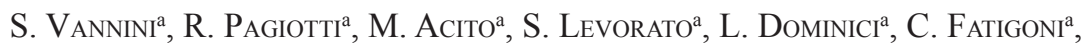 \\ V. GianFredi ${ }^{\mathrm{a}, \mathrm{b}}$, M. MoretTI ${ }^{\mathrm{a}}$ and M. VilLARINI ${ }^{\mathrm{a}, *}$ \\ ${ }^{a}$ Department of Pharmaceutical Sciences, University of Perugia, Via del Giochetto, 06122 Perugia Italy \\ ${ }^{b}$ Department of Experimental Medicine, Graduate School of Specialization in Hygiene and Preventive Medicine, \\ University of Perugia, Piazzale Gambuli, 06129 Perugia Italy
}

(Received: 22 August 2017; accepted: 14 November 2017)

\begin{abstract}
The alkenylbenzene estragole (systematic name, 1-allyl-4-methoxybenzene) is a natural component of essential oils from various spices and herbs, including fennel, and it is used as a food and beverage flavouring agent. Estragole has been reported to be hepatocarcinogenic at high doses in rodents. However, in a previous in vitro study, we found that estragole did not exhibit cytotoxic effects after 4 hours of exposure, nor did it induce DNA damage or apoptosis in human HepG2 hepatoblastoma cells. As fennel tea is widely used for symptomatic treatment of spasmodic gastrointestinal conditions in infants, we aimed at further assessing its safety in a different experimental setting. We thus searched for possible cytogenetic effects and interference with cell-cycle progression in the same human hepatoblastoma cell line. Estragole did not show any clastogenic/aneugenic activities in the cytokinesis-block micronucleus assay, and no effects on cell-cycle checkpoints were observed.
\end{abstract}

Keywords: estragole, HepG2 cells, micronuclei, genotoxicity, cell-cycle

The alkenylbenzene estragole (systematic name: 1-allyl-4-methoxybenzene) is a natural constituent of essential oils from a variety of spices and herbs such as nutmeg, basil, anise, mace, tarragon, fennel, and pimento. Extracts of these herbs have been used as flavouring agents mostly in baked goods, non-alcoholic beverages, and candy (Sмітн et al., 2002). Estragole intake from all sources ranges from $0.01 \mathrm{mg} / \mathrm{kg}$ bw (Sмiтн et al., 2002) to $0.07 \mathrm{mg} / \mathrm{kg}$ bw (EC, 2001), mostly originating from fennel infusions, widely used as an antispasmodic remedy. Infants represent the widest consumer group of fennel tea, to treat symptoms of spasmodic gastrointestinal illnesses (VAN DEN BERG et al., 2014). Estragole is, however, hepatocarcinogenic at high doses in rodents because of its bioactivation by cytochromes of the P450 family. In fact, estragole is quickly absorbed by the gastrointestinal tract, and is thereby transported to the liver, where it is catabolised along two distinct metabolic pathways (Punt et al., 2010; PainI et al., 2012; Villarini et al., 2014).

Because of the presumed genotoxicity and rodent carcinogenicity of some of its metabolites, the use of estragole as a pure substance in foodstuffs has been prohibited within the European Union since September 2008 (EC, 2008). In line with the recommendations for any supposed genotoxic/carcinogenic compound, the European Food Safety Authority (EFSA) has recently indicated that, as to the amount estragole to be allowed in herbal preparations, including fennel-based teas, a Margin of Exposure (MoE) approach (EFSA,

\footnotetext{
* To whom correspondence should be addressed.

Phone: +39 075 5857419; fax: +39075 5857428; e-mail: milena.villarini@unipg.it
} 
2005 ) should be applied in evaluating any potential risks in humans and the priority for risk management actions (EFSA, 2009a). The MoE is defined as the ratio between exposure levels causing malignant tumours in experimental animals (e.g. the BMDL10 value, the lower bound of the confidence interval of the benchmark dose that gives a $10 \%$ extra incidence of cancer) and the estimated daily intake in humans.

Based on experimental exposure data of estragole resulting from the consumption of homemade fennel tea and on BMDL10 values derived from the incidence of malignant liver tumours in female CD-1 mice exposed to estragole, different MoE values have been calculated (Miller et al., 1983; EFSA, 2009b; RAFFo et al., 2011; van den Berg et al., 2014). RAFFo and co-workers (2011) reported a MoE value ranging from 870 to 3,210, with these values being lower than 10000 and thus indicating a potential risk for human health and a priority for risk management actions. In contrast, VAN DEN BERG and co-workers (2014) reported MoE values that were generally above the default value of 10000 (i.e. 25 samples out of 34). Such discrepancies in MoE values are likely the consequence of different procedures in estimating the daily intake levels in the same exposure scenario. In fact, different methods for exposure evaluation (e.g., theoretical vs. experimental) and differences in extraction efficiency of estragole from a vegetal matrix are major sources of uncertainty in safety assessment. Moreover, criticisms have been raised regarding the extrapolation of carcinogenicity data from animal models to humans. In this context, one important issue to consider is whether the reported genotoxic and/or carcinogenic effects are a high-dose-related phenomenon; in this case, the effect would not occur under the conditions typical of human exposure. It might also be important to consider how the compound is metabolized, as the process may be different between animals and humans, and this may thus result in marked differences in toxicity.

In a previous study (VILLARIN et al., 2014), we have assessed the cytotoxic, genotoxic (primary DNA damage evaluated by the 'comet' assay), and apoptotic activities of estragole in the human hepatoblastoma cell line HepG2. Data reported in the above-mentioned paper demonstrated that estragole, under the adopted experimental conditions, was not cytotoxic, and it failed to induce DNA damage or apoptosis. However, a limitation of the comet assay is that aneugenic effects and indirect DNA fidelity interaction liabilities - including effects on cell-cycle checkpoints - are not detectable (WiTTE et al., 2007).

In this work, we have addressed these issues in human liver (HepG2) cells treated for 24 hours with three concentrations of estragole. Clastogenic and aneugenic events were evaluated by the cytokinesis-block micronucleus (CBMN) assay; cell-cycle analysis was conducted by DNA content quantification (fluorescence microscopy and image analysis) and hence, measurements of cell-cycle stage (e.g. $\mathrm{G}_{1} / \mathrm{G}_{0}, \mathrm{~S}$, or $\mathrm{G}_{2} / \mathrm{M}$ phase). The HepG2 hepatoblastoma-derived cell line was originally established in 1979 from the liver tissue of a 15-year-old Caucasian boy (ADEN et al., 1979), and listed on the ATCC (American Type Culture Collection, Rockville, MD, USA) repository as a human cell line (HB 8065). HepG2 cells retain many metabolic characteristics of hepatocytes; in particular, they have been reported to express cytochrome P450 (CYP) 1A2-dependent enzymes (involved in phase I reactions) and sulfotransferase (SULT) 1A1 (phase II reactions) responsible for estragole metabolism (WesterinK \& SCHOONEn, 2007). 


\section{Materials and methods}

\subsection{Chemicals and reagents}

Estragole (IUPAC name: 1-methoxy-4-prop-2-enylbenzene; CAS No: 140-67-0) was purchased from Sigma-Aldrich Italia Srl, Milan, Italy, with purity certified to be $\geq 98.5 \%$. All reagents were analytical grade unless otherwise stated.

\subsection{Cell cultures and exposure}

HepG2 cells (ATCC HB 8065) were obtained from Istituto Zooprofilattico Sperimentale della Lombardia e dell'Emilia Romagna 'Bruno Ubertini' (Brescia, Italy). Cells were grown as monolayer cultures and sub-cultured for in vitro testing, as described in detail elsewhere (VILLARINI et al., 2014; LOMBARDI et al., 2015).

\subsection{Lactate dehydrogenase $(\mathrm{LDH})$ assay}

The concentrations of estragole tested in the lactate dehydrogenase (LDH) assay were: 84.55 , $42.28,21.14,10.57,5.28,2.64,1.32,0.66$, and $0.33 \mu \mathrm{g} \mathrm{ml}^{-1}$. These concentrations were chosen following the test method protocol for solubility determination (NICEATM/ICCVAM, 2006). LDH activity was measured in culture media as an index of cytotoxicity using the Takara's LDH Cytotoxicity Detection Kit (Takara Bio Inc. Otsu, Japan), and absorbance was recorded using a Tecan Sunrise microplate reader (Tecan Italia Srl, Milan, Italy). Experiments had been done in triplicate. Cytotoxicity was expressed as percent LDH activity present in supernatants of estragole-treated cells relative to that in cells incubated with 1\% Triton X-100.

\subsection{Cytokinesis-block micronucleus (CBMN) test}

Estragole was tested in the cytokinesis-block micronucleus (CBMN) test using the three highest non-cytotoxic concentrations defined in the LDH assay. The CBMN test was performed according to the original method (FENECH, 2000) with minor modifications. Steps of the CBMN test are as described in detail elsewhere (Dominici et al., 2010; VILLARINI et al., 2011). For each experimental group, 1000 BNC (binucleated cells) were analysed, and the $\mathrm{MN}$ frequency was calculated based on established criteria (FENECH, 2000). Furthermore, to investigate the impact of the tested compound on cell proliferation, the nuclear division index (NDI) was calculated for each experimental point (EASTMOND \& TUCKER, 1989). The results for $\mathrm{MN}$ and NDI were expressed as the mean \pm standard deviation of triplicate determinations from independent experiments.

\subsection{Analysis of cell-cycle}

As for the CBMN test, cell-cycle analysis was carried out using the three highest noncytotoxic concentrations of estragole defined by the LDH assay. Cells were plated in six-well plates at $10^{6}$ cells per well and cultured for 24 hours. Cell cultures were then exposed to estragole for 24 hours. At the end of the treatment, cells were harvested, fixed with $70 \%$ ethanol, and maintained at $0-4{ }^{\circ} \mathrm{C}$ for 24 hours. After centrifugation, cell pellets were washed with PBS and treated for $5 \mathrm{~min}$ at $37^{\circ} \mathrm{C}$ with $0.5 \mathrm{ml}$ of PBS containing $1 \mu \mathrm{g} \mathrm{ml}^{-1} \mathrm{DAPI}$ and $0.1 \%$ triton $\mathrm{X}-100$. After staining, DAPI fluorescence was quantified by fluorescence microscopy with the automated cytometer NucleoCounter® ${ }^{\circledR}$ C-3000 ${ }^{\mathrm{TM}}$ (ChemoMetec A/S, Allerød, Denmark). 


\subsection{Statistical analysis}

Data were analysed using the statistical package SPSS (SPSS Inc., IL, USA). Variables were tested for normality with the Kolmogorov-Smirnov test. Statistical significance of differences was evaluated by one-way analysis of variance (ANOVA), followed by Dunnet post hoc analysis. To check for the occurrence of concentration-dependent responses, Pearson's correlation coefficients $(r)$ were calculated. The chosen level of significance was 0.05 .

\section{Results and discussion}

\subsection{Cytotoxicity}

Only exposure to the highest concentration of estragole $\left(84.55 \mu \mathrm{g} \mathrm{ml}^{-1}\right)$ caused clearly cytotoxic effects (percent cytotoxicity: 20.35 \pm 3.60 ) and, therefore, this concentration was not suitable for use in the subsequent experiments, as genotoxicity and cell-cycle tests need viability equal or superior to $80 \%$ to be performed. All the other concentrations tested resulted to be not cytotoxic (data not shown).

\subsection{Cytokinesis-block micronucleus test}

The number of micronuclei (MN) per $1000 \mathrm{BNC}$ was assessed as a measure of chromosomal abnormalities via the CBMN test in HepG2 cells exposed to a range of estragole concentrations. Based on cytotoxicity data, the CBMN test was carried out by testing $42.28,21.14$, and 10.57 $\mu \mathrm{g} \mathrm{ml}^{-1}$ estragole. A minor increase in MN (number of micronuclei) was observed when cells were exposed to the highest concentration tested relative to MN frequency in negative controls (Table 1), however, the increase did not reach the level of significance. Additionally, NDI - measured to verify any possible cytostatic effects of estragole - did not decrease significantly when compared to control cells (Table 1).

Table 1. Induction of micronuclei in human HepG2 cells by estragole

\begin{tabular}{lcc}
\hline Estragole & MN/1000 BNC & NDI \\
\hline $42.28 \mu \mathrm{g} \mathrm{ml}^{-1}$ & $7.00 \pm 1.26$ & $1.75 \pm 0.06$ \\
$21.14 \mu \mathrm{g} \mathrm{ml}^{-1}$ & $6.67 \pm 0.73$ & $1.68 \pm 0.09$ \\
$10.57 \mu \mathrm{g} \mathrm{ml}^{-1}$ & $5.67 \pm 0.60$ & $1.74 \pm 0.08$ \\
Negative control & $4.83 \pm 0.44$ & $1.72 \pm 0.04$ \\
Positive control & $11.67 \pm 1.09$ & $1.75 \pm 0.05$ \\
\hline
\end{tabular}

$\mathrm{MN}$ : micronuclei; BNC: binucleated cells; NDI: nuclear division index

\subsection{Analysis of cell-cycle}

The same concentrations as those used in the CBMN test were also used for cell-cycle analysis. As shown in Figure 1, treatment with estragole resulted in changes in cell-cycle distribution of HepG2 cells that were characterized by a minor accumulation of cells in the $\mathrm{G}_{0} / \mathrm{G}_{1}$ phase in a concentration-dependent manner $(\mathrm{r}=0.506 ; \mathrm{P}=0.046)$. Simultaneously, a 
non-significant reduction in number of cells in the $\mathrm{G}_{2} / \mathrm{M}$ phase after 24 hours exposure to estragole was detected.

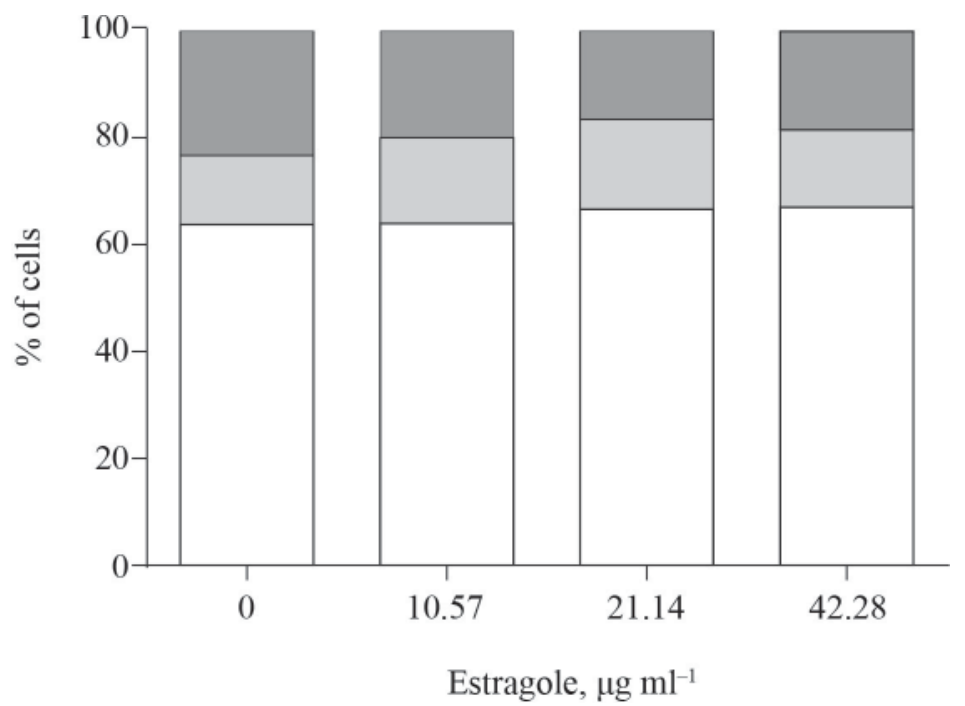

Fig. 1. Cell-cycle distribution of human hepatoma HepG2 cells treated for 24 hours with different concentrations of estragole

: $\mathrm{G}_{2} / \mathrm{M} ; \mathrm{I} ; \mathrm{S} ; \mathrm{G}_{0} / \mathrm{G}_{1} ; \mathrm{G}$ : gap phase; S: synthesis; M: mitosis

GoRI and co-workers (2012) have suggested that rodent carcinogenicity tests probably overestimate the risk of estragole carcinogenicity. In fact, the hepatocarcinogenicity of estragole in mice has clearly been related to its conversion to 1'-hydroxyestragole, and factors influencing its formation - or the balance between formation of the active metabolites (i.e. 1'-sulfooxyestragole and epoxides) and detoxification by glucuronidation - may also cause a related variation in the incidence of tumours (Jeurissen et al., 2007; SuzUKI et al., 2012). In male rats, O-demethylation of estragole (leading to detoxification of the compound) appears to be a major metabolic route when low doses of estragole are involved, with demethylation occurring mainly in lungs and kidneys. Conversely, when rats are exposed to high doses of estragole, as a result of saturation of the O-demethylation pathway in lungs and kidneys, formation of the proximate carcinogenic metabolite 1'-hydroxyestragole becomes relatively more important in liver. The physiologically-based biokinetic (PBBK) model predicts that formation of this metabolite in male rats would increase from $16 \%$ of the dose of $0.07 \mathrm{mg} / \mathrm{kg}$ bw to $29 \%$ of the dose of $300 \mathrm{mg} / \mathrm{kg}$ bw. In contrast, no relative increase in formation of 1'-sulfooxyestragole was identified in humans with increasing estragole dose levels (RIETJENs et al., 2010). These data point to different metabolic pathways of estragole in different species.

Concerning in vitro assays, the literature on genetic toxicology of estragole is scant and often with equivocal results. Estragole concentrations of $0.01-1 \mathrm{mM}$ did not induce the formation of chromosomal aberrations in the V79 cell line, with and without exogenous biotransformation systems (S9) or in primary rat hepatocytes (MuLLER et al., 1994). On the contrary, an increase in sister chromatid exchange (SCE) and of DNA damage were observed 
in V79 cells without metabolic activation at high doses (MARTINs et al., 2012). Evidence of genotoxicity in in vitro studies comes from the unscheduled DNA synthesis assay in rat hepatocytes (Chan \& CAldwell, 1992; Muller et al., 1994; Nesslany et al., 2010).

To the best of our knowledge, there are only two articles dealing with the genotoxicity of estragole in human cell lines (ZHOU et al., 2007; VILLARINI et al., 2014). In both studies, the cells being used were the human hepatoblastoma HepG2 line, and the estragole concentrations being assayed were comparable. ZHоU and co-workers (2007) found an increase in DNA adducts at $24 \mathrm{~h}$ of incubation. In contrast, our previous study (VILLARINI et al., 2014) showed the estragole treatment for $4 \mathrm{~h}$ would induce neither cytotoxic effects nor DNA damage or apoptosis.

Along this line, we have here observed a very minor and dose-dependent increase in $\mathrm{MN}$ frequency at $24 \mathrm{~h}$ of treatment leading to the conclusion that the genotoxicity of estragole is negligible when measured by the CBMN assay. Furthermore, estragole increased the percentage of cells in $\mathrm{G}_{0} / \mathrm{G}_{1}$ and decreased those in $\mathrm{G}_{2} / \mathrm{M}$, indicating an inhibition of HepG2 cells proliferation via impaired progression of cells from the $\mathrm{G}_{1}$ phase of cell-cycle. Among the three principal checkpoints controlling the cell cycle in eukaryotes, $\mathrm{G}_{1} / \mathrm{S}$, located at the end of the cell cycle's $G_{1}$ phase, makes the key decision of whether the cell should divide, delay division, or enter a resting stage. The loss of checkpoints provides growth advantages to proliferating cancer cells and is thus involved in tumourigenesis and tumour progression (Prindull, 2008).

\section{Conclusions}

In summary, the data presented provide novel evidence that estragole does not induce MN formation in HepG2 human cells and that it appears to have relatively weak ability to modulate cell-cycle. However, because estragole genotoxicity is a complex function based on different dose-related mechanisms, further studies are required to further establish the safety of estragole in human foods.

This work was supported by the University of Perugia (Grant "Ricerca di Base 2014").

The authors are grateful to Prof. Paolo Puccetti, Department of Experimental Medicine, University of Perugia, for reading the manuscript and offering constructive comments.

\section{References}

Aden, D.P., Fogel, A., Plotkin, S., Damjanov, I. \& Knowles, B.B. (1979): Controlled synthesis of HBsAg in a differentiated human liver carcinoma-derived cell line. Nature, 282(5739), 615-616.

CHAN, V.S. \& CALDWELl, J. (1992): Comparative induction of unscheduled DNA synthesis in cultured rat hepatocytes by allylbenzenes and their 1'-hydroxy metabolites. Food Chem. Toxicol., 30(10), 831-836.

Dominici, L., Cerbone, B., Villarini, M., Fatigoni, C. \& Moretti, M. (2010): In vitro testing for genotoxicity of indigo naturalis assessed by micronucleus test. Nat. Prod. Commun., 5(7), 1039-1042.

EAstmond, D.A. \& Tucker, J.D. (1989): Identification of aneuploidy-inducing agents using cytokinesis-blocked human lymphocytes and an antikinetochore antibody. Environ. Mol. Mutagen., 13(1), 34-43.

EC (2001): Opinion of the Scientific Committee on Food on estragole (1-allyl-4-methoxybenzene). European Commission, Brussels.

EC (2008): Regulation (EC) no 1334/2008 of the European Parliament and of the Council of 16 December 2008 on Flavourings and Certain Food Ingredients with Flavouring Properties for Use in and on Foods and Amending 
Council Regulation (EEC) No 1601/91, Regulations (EC) No 2232/96 and (EC) No 110/2008 and Directive 2000/13/EC. OJ EC. L 354, 34-50.

EFSA (2005): Opinion of the Scientific Committee on a request from EFSA related to a harmonised approach for risk assessment of substances which are both genotoxic and carcinogenic. EFSA J., 282, 1-31.

EFSA (2009a): Guidance on safety assessment of botanicals and botanical preparations intended for use as ingredients in food supplements, on request of EFSA. EFSA J., 7, 1249 (on-line).

EFSA (2009b): EFSA Scientific Cooperation (ESCO) Working Group on Botanicals and Botanical Preparations; Advice on the EFSA guidance document for the safety assessment of botanicals and botanical preparations intended for use as food supplements, based on real case studies on request of EFSA. EFSA J., 7(9), $280 \mathrm{http} / / /$ onlinelibrary.wiley.com/doi/10.2903/j.efsa.2009.280/full (last accessed 14 November 2017)

Fenech, M. (2000): The in vitro micronucleus technique. Mutat. Res., 455(1-2), 81-95.

Gori, L., Gallo, E., Mascherini, V., Mugelli, A., Vannacci, A. \& Firenzuoli, F. (2012): Can estragole in fennel seed decoctions really be considered a danger for human health? A fennel safety update. Evid. Based Comp. Alt., 2012, 860542.

Jeurissen, S.M., Punt, A., Boersma, M.G., Bogaards, J.J., Fiamegos, Y.C., Schilter, B., Van Bladeren, P.J., CnubBen, N.H. \& Rietsens, I.M. (2007): Human cytochrome p450 enzyme specificity for the bioactivation of estragole and related alkenylbenzenes. Chem. Res. Toxicol., 20(5), 798-806.

Lombardi, G., Vannini, S., Blasi, F., Marcotullio, M.C., Dominici, L., Villarini, M., Cossignani, L. \& Moretti, M. (2015): In vitro safety/protection assessment of resveratrol and pterostilbene in a human hepatoma cell line (HepG2). Nat. Prod. Commun., 10(8), 1403-1408.

Martins, C., Cacao, R., Cole, K.J., Phillips, D.H., Laires, A., RuefF, J. \& Rodrigues, A.S. (2012): Estragole: a weak direct-acting food-borne genotoxin and potential carcinogen. Mutat. Res., 747(1), 86-92.

Miller, E.C., Swanson, A.B., Phillips, D.H., Fletcher, T.L., Liem, A. \& Miller, J.A. (1983): Structure-activity studies of the carcinogenicities in the mouse and rat of some naturally occurring and synthetic alkenylbenzene derivatives related to safrole and estragole. Cancer Res., 43(3), 1124-1134.

Muller, L., Kasper, P., Muller-Tegethoff, K. \& Petr, T. (1994): The genotoxic potential in vitro and in vivo of the allyl benzene etheric oils estragole, basil oil and trans-anethole. Mutat. Res., 325(4), 129-136.

Nesslany, F., Parent-Massin, D. \& Marzin, D. (2010): Risk assessment of consumption of methylchavicol and tarragon: the genotoxic potential in vivo and in vitro. Mutat. Res., 696(1), 1-9.

NICEATM/ICCVAM (2006): Test method protocol for solubility determination; In vitro cytotoxicity validation study phase III. National Institute of Environmental Health Sciences (NIEHS); Research Triangle Park, NC (USA).

Paini, A., Punt, A., Scholz, G., Gremaud, E., Spenkelink, B., Alink, G., Schilter, B., Van Bladeren, P.J. \& Rietjens, I.M. (2012): In vivo validation of DNA adduct formation by estragole in rats predicted by physiologically based biodynamic modelling. Mutagenesis, 27(6), 653-663.

PRINDULL, G. (2008): Final checkup of neoplastic DNA replication: evidence for failure in decision-making at the mitotic cell cycle checkpoint G(1)/S. Exp. Hematol., 36(11), 1403-1416.

Punt, A., Jeurissen, S.M., Boersma, M.G., Delatour, T., Scholz, G., Schilter, B., Van Bladeren, P.J. \& Rietjens, I.M. (2010): Evaluation of human interindividual variation in bioactivation of estragole using physiologically based biokinetic modeling. Toxicol. Sci., 113(2), 337-348.

Raffo, A., Nicoli, S. \& LeclercQ, C. (2011): Quantification of estragole in fennel herbal teas: implications on the assessment of dietary exposure to estragole. Food Chem. Toxicol., 49(2), 370-375.

Rietjens, I.M., Punt, A., Schilter, B., Scholz, G., Delatour, T. \& Van Bladeren, P.J. (2010): In silico methods for physiologically based biokinetic models describing bioactivation and detoxification of coumarin and estragole: implications for risk assessment. Mol. Nutr. Food Res., 54(2), 195-207.

Smith, R.L., Adams, T.B., Doull, J., Feron, V.J., Goodman, J.I., Marnett, L.J., Portoghese, P.S., Waddell, W.J., Wagner, B.M., Rogers, A.E., Caldwell, J. \& Sipes, I.G. (2002): Safety assessment of allylalkoxybenzene derivatives used as flavouring substances - methyl eugenol and estragole. Food Chem. Toxicol., 40(7), 851870.

Suzuki, Y., Umemura, T., Hibi, D., Inoue, T., Jin, M., Ishi, Y., SAKai, H., Nohmi, T., Yanai, T., Nishikawa, A. \& OGAWA, K. (2012): Possible involvement of genotoxic mechanisms in estragole-induced hepatocarcinogenesis in rats. Arch. Toxicol., 86(10), 1593-1601.

van den Berg, S.J., Alhusainy, W., Restani, P. \& Rietjens, I.M. (2014): Chemical analysis of estragole in fennel based teas and associated safety assessment using the Margin of Exposure (MOE) approach. Food Chem. Toxicol., 65, 147-154. 
Villarini, M., Fatigoni, C., Cerbone, B., Dominici, L., Moretti, M. \& Pagiotti, R. (2011): In vitro testing of a laxative herbal food supplement for genotoxic and antigenotoxic properties. J. Med. Plants Res., 5(12), 25332539.

Villarini, M., Pagiotti, R., Dominici, L., Fatigoni, C., Vannini, S., Levorato, S. \& Moretti, M. (2014): Investigation of the cytotoxic, genotoxic, and apoptosis-inducing effects of estragole isolated from fennel (Foeniculum vulgare). J. Nat. Prod., 77(4), 773-778.

Westerink, W.M. \& Schoonen, W.G. (2007): Phase II enzyme levels in HepG2 cells and cryopreserved primary human hepatocytes and their induction in HepG2 cells. Toxicol. In Vitro, 21(8), 1592-1602.

Witte, I., Plappert, U., De Wall, H. \& Hartmann, A. (2007): Genetic toxicity assessment: employing the best science for human safety evaluation Part III: The comet assay as an alternative to in vitro clastogenicity tests for early drug candidate selection. Toxicol. Sci., 97(1), 21-26.

Zhou, G.D., Moorthy, B., Bi, J., Donnelly, K.C. \& Randerath, K. (2007): DNA adducts from alkoxyallylbenzene herb and spice constituents in cultured human (HepG2) cells. Environ. Mol. Mutagen., 48(9), 715-721. 